\title{
Biochemical changes of Moringa seeds extracts on Nile Tilapia breeding fish
}

\section{Emad M. Gad'; Ahmed A. Abd El-Rahman²; Adel M. Shalaby ${ }^{2}$ and Shimaa M. Metwally ${ }^{2 *}$}

${ }^{1}$ Chemistry Department, faculty of science, Suez Canal University.

${ }^{2}$ Fish physiology Department, central Laboratory for Aquaculture Research, Abbassa, Abo-Hammad, Sharkia, Egypt.

*Corresponding author: shimaametwally2015@gmail.com

Received: March. 3, 2019; Accepted: March. 24, 2019 published: Vol.9 (1):77-95; 2019

\section{Abstract}

The present study was conducted to evaluate the effect of Moringa oleifera seeds extracts in two different solvents ethanol and petroleum ether on the reproductive performance and physiological state of Nile Tilapia. Fish were stocked in 15 concrete ponds, grouped into 5 treatments in triplicates for each treatment. The first treatment T1 (control without any moringa extract), the second $\mathrm{T} 2$ and the third $\mathrm{T} 3$ (containing respectively $0.5 \mathrm{~g}$ and $1 \mathrm{~g}$ of moringa seed ethanol extract (MSEE)/kg diet), the fourth $\mathrm{T} 4$ and the fifth $\mathrm{T} 5$ (containing respectively $0.5 \mathrm{~g}$ and $1 \mathrm{~g}$ of moringa seed petroleum ether extract (MSPEE)/kg diet). The experiment extended to 70 days. The results showed that the highest numbers of fry production and ovaries weights were obtained with $\mathrm{T} 4$ and T5. The best treatment for blood hematological parameters is T4 and the highest level of testosterone and esteradiol hormones were observed in all moringa treatments. Thus it was concluded that $0.5 \mathrm{~g}$ of Moringa seed petroleum ether extract $/ \mathrm{kg}$ was useful for the improvement of the reproductive performance and physiological blood characteristics of brooding stock Nile tilapia fish.

Keywords: Moringa oleifera, seeds, extracts, Biochemical, Nile Tilapia, and Breeding.

\section{INTRODUCTION}

Aquaculture is the fastest growing sector of food production, about 50 percent of total global food fish production now comes from aquacultures. It is estimated that by2030, the world will require the production of an additional 27 million tons of fishery products to satisfy the growing demand for food fish (FAO 2016). Tilapia is a widespread fresh water 
cultured fish that can be reared under wide ranges of environmental conditions and can accept different protein sources in its diet (Welker and Lim, 2011). Reproduction process constitutes the main factor affects on any production yield, thus the financial outcome from aquaculture projects. Reproductive process is regulated by many elements; fish species, nutrition and environment are the master leading elements. Unfortunately, the effects of these neutraceuticals on reproduction and gamete quality, is still poorly studied (Giorgini et al., 2010). Feeding chickens with Moringa leaves and seeds will improve egg production. The inclusion of Moringa oleifera leaves meal up to $30 \%$ in the diet of growing traditional chickens had no negative impact on live body weight (Worku, 2016).

Plant oil from Moringa oleifera seeds are in high demand for their medicinal value. Apart from the medicinal uses, M. oleifera was reported to be a good source of vitamins and amino acids. The seeds of Moringa are considered to be antipyretic, acrid, and bitter and reported to show antimicrobial activity (Olugbemi $\boldsymbol{e t}$ al, 2010).

Moringa seed oil is considered equivalent to olive oil in terms of its chemical properties and contains a large quantity of tecopherol (Mani $\boldsymbol{e t}$ $\boldsymbol{a l}, \mathbf{2 0 0 7})$. The unique property is the ability of its dry, crushed seed and seed press cake, which contain polypeptides, to serve as natural coagulants for water treatment. The aqueous solution of Moringa seed is a heterogeneous complex mixture having various functional groups, mainly low molecular weight organic acids (amino acids). These amino acids have been found to constitute a physiologically active group of binding agents, working even at a low concentration, which because of the ability to interact with metal ions is likely to increase the sorption of metal ions (Anwar et al., 2007).

Ogunjinmi and Oladipo (2012) showed that hexane and methanolic extracts of Moringa seed contained the secondary metabolite such as alkaloid, glycoside, flavonoid, tannins, saponin, steroid and reducing sugar which make the seed of Moringa oleifera to posses the biological properties. The Moringa seed oil is high $(80.4 \%)$ in polyunsaturated fatty acid; The dry matter basis of Moringa oleifera seeds contained $34.80 \%$ ether extract, $31.65 \%$ protein, $7.54 \%$ fiber, $8.90 \%$ moisture, and $6.53 \%$ ash contents (Ogbunugafor $\boldsymbol{e t}$ al., 2011).

Jabeen et al. (2008) mentioned that the antimicrobial properties of the $M$. oleifera seed extracts may be due to lipophilic compounds. These compounds may attach to the cytoplasmic membrane. M. oleifera seed powder is a good water purifier; and contains polyelectrolytes, which 
constitute active ingredients in water treatment. Aqueous extract of mature seeds from trees and shrubs of Moringacae family are effective in clarifying turbid and waste water in tropical countries.

The most common phytochemical contents present in moringa seeds include flavonoids (13.09\%), alkaloids (12.28\%), tannin (5.32\%), saponins $(1.37 \%)$ and cyanide $(0.05 \%)$, while the proximate analysis were reported as; moisture $(4.77 \%)$, ash $(1.71 \%)$, protein $(31.04 \%)$, crude fiber $(1.17 \%)$, fat $(21.25 \%)$ and carbohydrate $(40.06 \%)$ (Olorode et al., 2014). The effect of Moringa seed powder on the gonadal integrity of Mozambique Tilapia, Oreochromis mossambicus indicated that Moringa seed powder at $5.0 \mathrm{~g} / \mathrm{kg}$ basal diet and higher inclusion levels have an antifertility effect, significantly affecting gonad integrity and sperm production in sexually mature $O$. mossambicus males (Ampofo-Yeboah et al., 2013). These studies carried out on the use of plant products (MSEE and MSPEE) on fish aquaculture and determination their biological effects on fish such as improvement of reproduction performance and physiological state of Nile Tilapia by improving in brood stock nutrition. The study aimed to evaluate the effect of different levels $(0.5 \mathrm{gm}$ and $1 \mathrm{gm} / \mathrm{kg}$ diet $)$ of moringa seeds ethanol extract MSEE and moringa seeds petroleum ether extract MSPEE on the reproduction performance, physiological state of Nile tilapia.

\section{MATERIAL AND METHODS}

The present study was carried out on the Central Laboratory for Aquaculture Research (CLAR), Abbassa, Abou-Hammad, Sharkia, Egypt. The feeding experiment was carried out at the Hatching and Physiology Department and extended 70 days.

\section{1- Collection and processing of plant materials:}

The fully mature dry seeds were round or triangular in shape and the kernel is surrounded by light wooded shell with three wings. The seeds were air-dried, the testa and wings were manually removed and the white kernel was ground to fine powder, using the coffee mill attachment of a Moulinex domestic food blender (Price, 2000).

\section{2- Preparation of $M$. oleifera seeds extracts:}

The powder samples of seeds were weighed individually accurately to the $50 \mathrm{~g}$, and placed on a clean and dry filter paper. The filter paper and its contents were placed in the central syphon portion of the Soxhlet apparatus. The analytical ethanol $95 \%$ was placed $(250 \mathrm{ml})$ in the flask and connected to the Soxhelt syphon and condenser. The samples were refluxed for 20 hours. This process was repeated and replaced ethanol as a 
solvent with petroleum ether $\left(60-80^{\circ} \mathrm{C}\right)$. The two extracts (Moringa seeds ethanol extract MSEE and Moringa seeds petroleum ether extract MSPEE) were then obtained after the removal of the extraction solvents by using a rotary evaporator at $50{ }^{\circ} \mathrm{C}$. This process was repeated until enough amounts of two extracts were obtained. The obtained dried extracts were weighed, kept in a capped container, labeled appropriately and stored at $-20^{\circ} \mathrm{C}$. (Abdel-Naby, 2014).

\section{3-Determination of chemical components of two extracts (MSEE and MSPEE) by Gas chromatographic analysis (GC-MS):}

The identification of constituents was based on a comparison of their mass spectra and retention time with those of the authentic compounds and by computer matching with NIST and WILLY library as well as by comparison of the fragmentation pattern of the mass spectral data with those reported in the literature.

\section{Gas Chromatographic (GC) techniques:}

MSEE and MSPEE were analyzed by gas chromatography using (Agilent Technologies 7890A) interfaced with a mass-selective detector (MSD, Agilent 7000) equipped with a polar Agilent HP-5ms (5\%-phenyl methyl poly siloxane) capillary column $(30 \mathrm{~m}$ x $0.25 \mathrm{~mm}$ i. d. and $0.25 \mu \mathrm{m}$ film thickness). The carrier gas was helium with the linear velocity of $1 \mathrm{ml} / \mathrm{min}$. The injector and detector temperatures were maintained at $200^{\circ}$ $\mathrm{C}$ and $270^{\circ} \mathrm{C}$, respectively. Volume injected $1 \mu \mathrm{l}$ of the sample. The MS operating parameters were as follows: ionization potential 70 electrons volt, interface temperature $250{ }^{\circ} \mathrm{C}$, and acquisition mass range $50-800$ (Abdel-Naby, 2014).

\section{4- Diet preparation:}

Table (1) showed all dry ingredients which mixed with Moringa seeds extracts (MSEs) of each diet then the mixture of each treatment was blended using kitchen blender to make a paste of each diet. Pelleting of each diet was carried out by passing the blended mixture through a laboratory pellet machine with $1 \mathrm{~mm}$ diameter matrix. The resulting wet pellets were dried at room temperature for two days. Five treatments were prepared (T2, T3, T4 and T5); T1 (control treatment without any extract), T2 and T3 contain 0.5 and $1 \mathrm{~g}$ of Moringa seeds ethanol extract/ kg (MSEE) respectively, T4 and T5 contain 0.5 and $1 \mathrm{~g}$ of Maringa seeds petroleum ether extract/ $\mathrm{kg}$ (MSPEE) respectively. The diets were stored in plastic bags in a refrigerator $\left(+2^{\circ} \mathrm{C}\right)$ until use. The proximate analysis of experimental diets showed that the diet contained $34.85 \%$ crude protein 
and $6.2 \%$ crude fat. Experimental diets were formulated according to NRC, (1993).

Table (1): Ingredients and chemical analysis of the experimental diet.

\begin{tabular}{|c|c|}
\hline Ingredients & Quantity \% \\
\hline Fish meal & 30 \\
\hline Soybean meal & 15 \\
\hline Rice bran & 21 \\
\hline Wheat bran & 16 \\
\hline Yellow corn & 14 \\
\hline Molasses & 2.75 \\
\hline Di calcium phosphate & 1 \\
\hline Vit \& minerals Premix & 0.25 \\
\hline Total & 100 \\
\hline Total chemical analysis (\%): \\
\hline Crude protein & 34.85 \\
\hline Crude fat & 6.20 \\
\hline Ash & 7.70 \\
\hline Crude fiber & 6.13 \\
\hline NFE & 45.12 \\
\hline
\end{tabular}

\section{5- Experimental fish:}

Healthy fish of 360 males and females $O$. niloticus were collected from Abbassa fish farm, Abu Hammad, Sharkia, Egypt. Fish samples contained 240 females and 120 males (2:1) with an average weight of $220 \mathrm{~g}$. Fish were distributed in 15 concrete ponds; each pond contained 16 females and 8 males; concrete ponds ( 9 × 2.5x $1.2 \mathrm{~m}$ ), where water depth in each pond was $0.7 \mathrm{~m}$. Fish were acclimated for 10 days in the same conditions. Fish Nile Tilapia was divided to 5 treatments, each treatment was triplicates. The first treatment (T1) left as control group, the second and the third treatment (T2 and T3) fed with 0.5 and $1 \mathrm{~g}$ of MSEE/ kg. The fourth and the fifth (T4 and T5) fed with diet contain 0.5 and 1 gm of MSPEE $/ \mathrm{kg}$. The feeding ration amounted $0.7 \%$ of total body weight daily by hand were divided into two equal parts and fed at 9.00 am and 1.00 pm.

\section{6- Production of fry:}

Fries were collected from the ponds early every morning every fifteen days. All fries samples were taken weighted and counted for each pond. Fries were transferred to nursing ponds.

\section{7- Fish growth and economic evaluation of brood stock.}


Growth performance was determined and feed utilization was calculated as follows:

Weight gain $=\mathrm{W} 2-\mathrm{W} 1$

Where $\mathrm{W} 1$ and $\mathrm{W} 2$ are the initial and final weights, respectively.

Feed required to produce 1000 fry, $(\mathrm{g})=$ total feed used, $(\mathrm{g} /$ pond $) /$ (fry no. / pond)

The cost of feed/1000 fry, LE= Feed required to produce 1000 fry, $(\mathrm{kg})^{*}$ the cost of one $\mathrm{kg}$ feed

\section{8- Hematological examination.}

6 fish ( 3 males and 3 females) from each of the treatments and control group were taken for physiological investigations at the end of the experimental period. Fish were not fed for 24 hours prior to blood sampling. Fish blood was collected from each fish caudal vein by a sterile syringe. Blood samples were divided into two parts; the first part was transferred on dry and clean tube with EDTA solution for measuring hemoglobin $(\mathrm{Hb})$, red blood cells (RBCs), hematocrite (Hct) in blood after good mixing. The second part was transferred in clean and dry tubes then centrifuged for 15 minutes at 3000 r.p.m for separation of serum (collected serum was stored at $-20^{\circ} \mathrm{C}$ ) for hormones analysis (testosterone, estradiol and cortisol).

Hematocrit was measured as packed cells volume by using micro hematocrit tubes method as described by Dacie and Lewis (1991). Haemoglobin $(\mathrm{Hb})$ concentration and blood indices (MCV, MCH and MCHC) were determined immediately according to (Vankampen, 1961)., Teststerone levels in serum of blood were measured by hormonal assays, which were done by Radio Immune Assay (RIA) using the kits supplied by (Coat-A-count) provided by Orion Diagnostic Spectra, Finland according to (Abraham, 1977). But estradiol in females was determined by the radioimmunoassay method according to Xing $\boldsymbol{e t}$ al. (1983) using Immun. Chem. kit, provided by Diagnostic Products Corporation, Los Angeles. All the brought fish were weighed to the nearest $0.1 \mathrm{~g}$ and plucked out gonads (testes and ovaries) and liver. The gonads and liver were weighed for each fish to calculate the gonado somatic index and hepato somatic index

Gonado somatic index (GSI) and Hepato or somatic index (HSI) were calculated from the following formula (Munkittrich and Dixon, 1988):

GSI $=($ Gonads weight $/$ body weight $) \times 100 \quad$ HSI $=($ liver weight $/$ body weight) $\times 100$ 


\section{Statistical analysis:}

One way analysis of variance (ANOVA) was conducted to test the effect of Moringa extracts on male/female efficiency on the spawning performance of breeding fish. This analysis was done using the computer program SPSS and least Significant difference (LSD) post hoc were done to determine significant differences (Tamhane and Dunlop, 2000).

\section{Results}

The yellow extracts obtained from MSEE and MSPEE were analyzed by gas chromatography and identified by comparing their retention times with that of authentic standards injected under identical conditions. Results of chemical composition of two extracts (ethanol and petroleum ether extracts are shown in tables 2 and 3, respectively). Tables results showed that Moringa extracts contain antioxidants compounds like (Quercetin 3'-methyl ether, 7, 4'-Dimethoxy-3-hydroxyflavone, Citronellic acid and Squalane); fatty acids compounds like (Linolenic acid, Tetradecanoic acid and Tetracosanoic acid); vitamins like (Ascorbic acid and Vitamin E).

Table (4) the results in this table showed that significantly increased in the fry number /pond, the fry number /female and female average wt (g) in all Moringa treatments when compared with the control group. The best results were showed in fish fed with 0.5 and $1 \mathrm{~g}$ of MSPEE $/ \mathrm{kg}$ diet (T4 and T5) as compared with control group throughout the breeding season.

The hematological parameters were recorded in table (5). The results of erythrocytes count (RBC) were significantly increased in all treatments compared with control group $\left(1.71 \pm 0.09 \times 10^{6} / \mathrm{cmm}\right)$. Erythrocytes count (RBC) was significantly high in T4 $\left(2.59 \pm 0.13 \times 10^{6} / \mathrm{cmm}\right)$. Hemoglobin $(\mathrm{Hb})$ content was significantly increased in all treatments compared with control group $(5.85 \pm 0.33 \mathrm{~g} / \mathrm{dl})$. Also the hematocrit value was significantly increased in T2 and T4 but no significant in T3 and T5.

Blood indices parameters were recorded in table (6). There were significant decreases in mean values of $\mathrm{MCV}$ in all treatments. There were variable changes of $\mathrm{MCH}$ and $\mathrm{MCHC}$ values.

Table (7) showed significant increases in estradiol hormones in T3, T4and T5 in blood serum of females Nile Tilapia after fed with diet containing 0.5 and $1 \mathrm{~g}$ of MSEs/kg when compared with control group. There were significant increases in cortisol hormone in all treatments compared with control group. The ovary weight and gonad somatic index 
in females Nile tilapia were significantly increased in T4 (MSPEE) and no significant decreases in HSI.

Table (2): Chemical composition of ethanol Moringa seeds extract analyzed by gas chromatography.

\begin{tabular}{|c|c|c|c|}
\hline No & $\begin{array}{l}\text { Retention } \\
\text { time (min) }\end{array}$ & Name & $\begin{array}{c}\text { Area sum } \\
\%\end{array}$ \\
\hline 1 & 10.574 & Quercetin 3'-methyl ether & 3.0 \\
\hline 2 & 12.375 & Tetradecanoic acid & 0.41 \\
\hline 3 & 13.577 & (S)-(-)-Citronellic acid & 4.24 \\
\hline 4 & 13.715 & 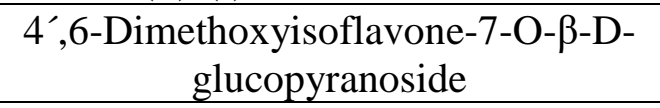 & 9.51 \\
\hline 5 & 13.841 & 7, 4'-Dimethoxy-3-hydroxyflavone & 1.67 \\
\hline 6 & 14.603 & Serotonin & 0.95 \\
\hline 7 & 14.835 & Linolenic acid & 38.09 \\
\hline 8 & 14.962 & Quercetin $3^{\prime}, 4^{\prime}, 7$ trimethyl ether & 9.10 \\
\hline 9 & 15.931 & Ascorbic acid, permethyl & 0.53 \\
\hline 10 & 16.253 & Dodecanedioic acid & 5.27 \\
\hline 11 & 16.486 & 3-Hydroxy-6,3',4'- trimethoxyflavone & 7.78 \\
\hline 12 & 16.657 & $\begin{array}{l}\text { 3-(3,4 -Dimethoxyphenyl)-6-methyl- } \\
\text { 4-phenylcoumarin }\end{array}$ & 0.54 \\
\hline 13 & 18.726 & $\begin{array}{c}\text { Quercetin } 3,5,7,3^{\prime}, 4^{\prime} \text {-pentamethyl } \\
\text { ether }\end{array}$ & 13.42 \\
\hline 14 & 18.983 & 6-methoxyluteolin & 1.06 \\
\hline 15 & 19.842 & Vitamin E & 1.57 \\
\hline 16 & 21.337 & Tetracosanoic acid & 0.84 \\
\hline 17 & 21.704 & $\beta$-Citronellol & 0.80 \\
\hline 18 & 22.967 & Squalane & 0.61 \\
\hline 19 & 20.466 & Phytanic acid & 0.59 \\
\hline \multicolumn{3}{|r|}{ Total } & 99.98 \\
\hline
\end{tabular}


Table (3): Chemical composition of petroleum ether Moringa seeds extract analyzed by gas chromatography.

\begin{tabular}{|c|c|c|c|}
\hline No & $\begin{array}{c}\text { Retention } \\
\text { time } \\
(\mathbf{m i n})\end{array}$ & Name & $\begin{array}{c}\text { Area } \\
\text { sum } \\
\text { \% }\end{array}$ \\
\hline $\mathbf{1}$ & 5.47 & 2- Decanol & 0.58 \\
\hline $\mathbf{2}$ & 6.635 & Undecane & 3.5 \\
\hline $\mathbf{3}$ & 7.706 & D-(+)-Mannose & 6.15 \\
\hline $\mathbf{4}$ & 10.623 & 6-methylchromone & 1.22 \\
\hline $\mathbf{5}$ & 10.700 & 3,6-dimethylchromone & 0.71 \\
\hline $\mathbf{6}$ & 10.855 & Santonox & 0.92 \\
\hline 7 & 11.360 & Germacrene D & 5.87 \\
\hline $\mathbf{8}$ & 11.466 & Nylidrin & 3.28 \\
\hline $\mathbf{9}$ & 11.633 & Thuga-2,4 (10)-diene & 2.26 \\
\hline $\mathbf{1 0}$ & 11.922 & Nopol (terpene) & 2.06 \\
\hline $\mathbf{1 1}$ & 12.085 & $\alpha-c u b e b e n e$ & 2.13 \\
\hline $\mathbf{1 2}$ & 12.118 & Cumic aldehyde & 2.30 \\
\hline $\mathbf{1 3}$ & 12.212 & P- Mentha-1,3,8- triene & 2.57 \\
\hline $\mathbf{1 4}$ & 12.374 & Cosmene & 2.38 \\
\hline $\mathbf{1 5}$ & & 2H-1-benzopyran-2-one, $7-$ & 2.24 \\
\hline $\mathbf{1 6}$ & 11.774 & hydroxy-4-methyl-3-phenyl & \\
\hline $\mathbf{1 7}$ & 12.831 & (-)-perillyl alcohol & 3.38 \\
\hline $\mathbf{1 8}$ & 12.920 & Aristolene & 1.9 \\
\hline $\mathbf{1 9}$ & 13.364 & 3- Caryophyllene & 2.0 \\
\hline $\mathbf{2 0}$ & 13.792 & Afromosin 7-O-glucoside & 1.04 \\
\hline $\mathbf{2 1}$ & 13.865 & Zearalenone & 2.06 \\
\hline $\mathbf{2 2}$ & 14.827 & 9-Octadecenoic acid, (E)- & 13.88 \\
\hline $\mathbf{2 3}$ & 14.921 & Cis-Vaccenic acid & 12.63 \\
\hline $\mathbf{2 4}$ & 15.405 & Retinol & 7.43 \\
\hline $\mathbf{2 5}$ & 19.915 & Vitamin E & 15.99 \\
\hline & & & 99.99 \\
\hline & & & \\
\hline
\end{tabular}


Table (4): The effect of different levels of Moringa seeds extracts on reproductive performance of Nile tilapia.

\begin{tabular}{|c|c|c|c|c|c|}
\hline Items & T1 & T2 & T3 & T4 & T5 \\
\hline Fry no./pond & 17407 & 20505 & 21377 & 22820 & 22357 \\
& $\pm 467^{\mathrm{d}}$ & $\pm 719^{\mathrm{c}}$ & $\pm 668^{\mathrm{bc}}$ & $\pm 291^{\mathrm{a}}$ & $\pm 487^{\mathrm{ab}}$ \\
\hline No of fry/ & 1088 & 1282 & 1336 & 1426 & 1397 \\
female & $\pm 29^{\mathrm{d}}$ & $\pm 45^{\mathrm{c}}$ & $\pm 42^{\mathrm{bc}}$ & $\pm 18^{\mathrm{a}}$ & $\pm 30^{\mathrm{ab}}$ \\
\hline Female final & 234.33 & 243.00 & 240.00 & 247.50 & 243.83 \\
wt (g) & $\pm 1.53^{\mathrm{d}}$ & $\pm 1.15^{\mathrm{b}}$ & $\pm 1.04^{\mathrm{c}}$ & $\pm 2.52^{\mathrm{a}}$ & $\pm 1.53^{\mathrm{b}}$ \\
\hline
\end{tabular}

Means having the same letter in the same row is not significantly different at $(\mathrm{P}<$ $0.05)$.

Table (5): The haematological changes (Hb, RBCs, Hct ) of the blood of Nile tilapia after fed with diet containing extract of moringa seeds.

\begin{tabular}{|c|c|c|c|c|c|}
\hline Items & T1 & T2 & T3 & T4 & T5 \\
\hline RBCs & 1.71 & 2.10 & 2.01 & 2.59 & 2.01 \\
$(\mathbf{X 1 0} / \mathbf{c m m})$ & $\pm 0.09^{\mathrm{c}}$ & $\pm 0.05^{\mathrm{b}}$ & $\pm 0.15^{\mathrm{b}}$ & $\pm 0.13^{\mathrm{a}}$ & $\pm 0.15^{\mathrm{b}}$ \\
\hline $\mathbf{H B}(\mathbf{g} / \mathbf{d l})$ & 5.85 & 6.90 & 6.79 & 7.14 & 6.79 \\
& $\pm 0.33^{\mathrm{c}}$ & $\pm 0.18^{\mathrm{b}}$ & $\pm 0.40^{\mathrm{b}}$ & $\pm 0.11^{\mathrm{a}}$ & $\pm 0.40^{\mathrm{b}}$ \\
\hline Het $(\%)$ & 16.87 & 18.90 & 16.83 & 21.64 & 16.83 \\
& $\pm 0.89^{\mathrm{c}}$ & $\pm 0.46^{\mathrm{b}}$ & $\pm 0.53^{\mathrm{c}}$ & $\pm 1.12^{\mathrm{a}}$ & $\pm 0.53^{\mathrm{c}}$ \\
\hline
\end{tabular}

Table (6): The haematological changes (MCV, $\mathrm{MCH}$ and $\mathrm{MCHC}$ ) of the blood of Nile tilapia after fed with diet containing extract of Moringa seeds.

\begin{tabular}{|c|c|c|c|c|c|}
\hline Items & T1 & T2 & T3 & T4 & T5 \\
\hline MCV $\left(\boldsymbol{\mu}^{\mathbf{3})}\right.$ & $98.76 \pm 4.39^{\mathrm{a}}$ & $82.33 \pm 3.74^{\mathrm{b}}$ & $83.31 \pm 4.97^{\mathrm{b}}$ & $90.91 \pm 6.78^{\mathrm{b}}$ & $83.93 \pm 4.97^{\mathrm{b}}$ \\
\hline $\mathbf{M C H}(\mathbf{P g})$ & $34.27 \pm 1.67^{\mathrm{a}}$ & $28.99 \pm 0.31^{\mathrm{ab}}$ & $28.02 \pm 1.52^{\mathrm{a}}$ & $31.75 \pm 1^{\mathrm{b}}$ & $33.82 \pm 1.52^{\mathrm{a}}$ \\
\hline $\mathbf{M C H C}(\boldsymbol{\%})$ & $34.78 \pm 3.03^{\mathrm{b}}$ & $35.22 \pm 1.35^{\mathrm{b}}$ & $33.76 \pm 1.21^{\mathrm{a}}$ & $34.94 \pm 1.95^{\mathrm{b}}$ & $40.33 \pm 1.21^{\mathrm{a}}$ \\
\hline
\end{tabular}


Table (7): The effect of different levels of Moringa seeds extracts on estradiol, cortisol, ovary weight, GSI and HSI of females Nile Tilapia.

\begin{tabular}{|c|c|c|c|c|c|}
\hline Items & T1 & T2 & T3 & T4 & T5 \\
\hline $\begin{array}{c}\text { Estradiol } \\
\text { (pg/ml) }\end{array}$ & $\begin{array}{c}204.00 \\
\pm 5.58^{\mathrm{c}}\end{array}$ & $\begin{array}{c}202.87 \\
\pm 3.01^{\mathrm{c}}\end{array}$ & $\begin{array}{c}227.33 \\
\pm 6.51^{\mathrm{b}}\end{array}$ & $\begin{array}{c}239.40 \\
\pm 5.77^{\mathrm{a}}\end{array}$ & $\begin{array}{c}231.53 \\
\pm 3.40^{\mathrm{a}}\end{array}$ \\
\hline $\begin{array}{c}\text { Cortisol } \\
\text { (ng/ml) }\end{array}$ & $\begin{array}{c}146.73 \\
\pm 6.75^{\mathrm{c}}\end{array}$ & $\begin{array}{c}164.13 \\
\pm 4.00^{\mathrm{a}}\end{array}$ & $\begin{array}{c}177.30 \\
\pm 6.65^{\mathrm{a}}\end{array}$ & $\begin{array}{c}156.50 \\
\pm 4.05^{\mathrm{b}}\end{array}$ & $\begin{array}{c}165.80 \\
\pm 3.67^{\mathrm{a}}\end{array}$ \\
\hline $\begin{array}{c}\text { Ovary wt } \\
\text { (gm) }\end{array}$ & $\begin{array}{c}4.00 \\
\pm 0.79^{\mathrm{c}}\end{array}$ & $\begin{array}{c}4.40 \\
\pm 0.97^{\mathrm{c}}\end{array}$ & $\begin{array}{c}4.84 \\
\pm 0.44^{\mathrm{b}}\end{array}$ & $\begin{array}{c}6.03 \\
\pm 1.17^{\mathrm{a}}\end{array}$ & $\begin{array}{c}4.41 \\
\pm 1.12^{\mathrm{c}}\end{array}$ \\
\hline GSI (\%) & $\begin{array}{c}1.71 \\
\pm 0.32^{\mathrm{c}}\end{array}$ & $\begin{array}{c}1.81 \\
\pm 0.36^{\mathrm{b}}\end{array}$ & $\begin{array}{c}2.02 \\
\pm 0.32^{\mathrm{b}}\end{array}$ & $\begin{array}{c}2.43 \\
\pm 0.97^{\mathrm{a}}\end{array}$ & $\begin{array}{c}1.81 \\
\pm 0.44^{\mathrm{b}}\end{array}$ \\
\hline HSI (\%) & $\begin{array}{c}1.87 \\
\pm 0.13^{\mathrm{b}}\end{array}$ & $\begin{array}{c}1.22 \\
\pm 0.22^{\mathrm{c}}\end{array}$ & $\begin{array}{c}1.47 \\
\pm 0.43^{\mathrm{bc}}\end{array}$ & $\begin{array}{c}1.56 \\
\pm 0.19^{\mathrm{b}}\end{array}$ & $\begin{array}{c}2.10 \\
\pm 0.13^{\mathrm{a}}\end{array}$ \\
\hline
\end{tabular}

Means having the same letter in the same row is not significantly different at $(\mathrm{P}<0.05)$.

Table (8) showed significant increases in T2, T3 and T4 in testosterone hormone level in serum of blood of male Nile Tilapia compared with control group after fed with diet containing 0.5 and $1 \mathrm{~g} / \mathrm{kg}$ of MSEs. There was no significant increase in testosterone level in T5. However there was a significant increase in all treatments in cortisol compared with control group. There were significant increases of testis weight and GSI in T4 and T5 compared with control group. There were significant decreases of HSI in T2, T3 and T5 compared with control group.

Table (8): The effect of different levels of Moringa seeds extracts on testosterone, cortisol, testis weight, GSI and HSI of males Nile tilapia.

\begin{tabular}{|c|c|c|c|c|c|}
\hline Items & T1 & T2 & T3 & T4 & T5 \\
\hline $\begin{array}{c}\text { Testosterone } \\
\text { (ng/ml) }\end{array}$ & $3.41 \pm 0.48^{\mathrm{c}}$ & $4.84 \pm 0.66^{\mathrm{b}}$ & $4.73 \pm 0.23^{\mathrm{b}}$ & $5.62 \pm 0.42^{\mathrm{a}}$ & $3.98 \pm 0.45^{\mathrm{c}}$ \\
\hline $\begin{array}{c}\text { Cortisol } \\
\text { (ng/ml) }\end{array}$ & $150.33 \pm 9.0^{\mathrm{c}}$ & $162.67 \pm 5.86^{\mathrm{b}}$ & $178.13 \pm 2 .^{\mathrm{a}}$ & $170.83 \pm 1.8^{\mathrm{b}}$ & $170.43 \pm 10.1^{\mathrm{b}}$ \\
\hline Testis wt(g) & $1.09 \pm 0.22 \mathrm{~b}^{\mathrm{b}}$ & $1.10 \pm 0.20^{\mathrm{b}}$ & $1.02 \pm 0.18^{\mathrm{b}}$ & $1.99 \pm 0.19^{\mathrm{a}}$ & $1.73 \pm 0.21^{\mathrm{a}}$ \\
\hline GSI (\%) & $0.49 \pm 0.11^{\mathrm{b}}$ & $0.5 \pm 0.08^{\mathrm{b}}$ & $0.47 \pm 0.06^{\mathrm{b}}$ & $0.90 \pm 0.09^{\mathrm{a}}$ & $0.78 \pm 0.08^{\mathrm{a}}$ \\
\hline HSI (\%) & $1.44 \pm 0.15^{\mathrm{a}}$ & $1.10 \pm 0.21^{\mathrm{b}}$ & $1.05 \pm 0.05^{\mathrm{b}}$ & $1.27 \pm 0.21^{\mathrm{a}}$ & $0.99 \pm 0.07^{\mathrm{b}}$ \\
\hline
\end{tabular}

Means having the same letter in the same row is not significantly different at $(\mathrm{P}<0.05)$.

Table (9) showed that feed required to producing 1000 fry by gram and its cost significant decreased in all treatments compared with control group. Although there are significant increases in total feed used, gm/pond in all treatments compared with control group, the cost of 
feed/1000 fry required to produce 1000 fry significant decreased and the best result T4 diet supplemented with $0.5 \mathrm{~g}$ of Moringa seeds petroleum ether extract.

Table (9): Economic evaluation and feed utilization efficiency of Nile Tilapia brood stock as affected with different levels of Moringa seeds extracts.

\begin{tabular}{|l|c|c|c|c|c|}
\hline \multicolumn{1}{|c|}{ Items } & T1 & T2 & T3 & T4 & T5 \\
\hline Fry no./pond & $17407 \pm 467^{\mathrm{d}}$ & $20505 \pm 719^{\mathrm{c}}$ & $21377 \pm 668^{\mathrm{bc}}$ & $22820 \pm 291^{\mathrm{a}}$ & $22357 \pm 487^{\mathrm{ab}}$ \\
\hline $\begin{array}{l}\text { Total feed } \\
\text { used,gm/pond }\end{array}$ & $2663 \pm 6.65^{\mathrm{b}}$ & $2707 \pm 1.52^{\mathrm{ab}}$ & $2720 \pm 3.46^{\mathrm{ab}}$ & $2747 \pm 1.52^{\mathrm{a}}$ & $2730 \pm 4.58^{\mathrm{ab}}$ \\
\hline $\begin{array}{l}\text { Feed required to } \\
\text { produce1000 } \\
\text { fry, }(\mathrm{gm})\end{array}$ & $153 \pm 7.21^{\mathrm{a}}$ & $132 \pm 5^{\mathrm{b}}$ & $127.3 \pm 4.16^{\mathrm{ab}}$ & $120.33 \pm 1.53^{\mathrm{c}}$ & $122.33 \pm 0.58^{\mathrm{c}}$ \\
\hline $\begin{array}{l}\text { The cost of } \\
\text { feed/1000 fry, } \\
\text { LE }\end{array}$ & $1.38 \pm 0.06^{\mathrm{a}}$ & $1.24 \pm 0.04^{\mathrm{b}}$ & $1.24 \pm 0.04^{\mathrm{b}}$ & $1.13 \pm 0.02^{\mathrm{c}}$ & $1.19 \pm 0.01^{\mathrm{bc}}$ \\
\hline
\end{tabular}

\section{Discussion}

Aquaculture is the main source to increase fish supply. Fast development of aquaculture and increasing fish demand lead to intensification of fish culture, Plant extracts on fish physiology as well as a lack of homogenization in the extract preparation and fish administration of the plant extracts. These studies carried out on the use of plant products on fish aquaculture and their biological effects on fish such as improvement of reproductive performance. Improvement in brood stock nutrition and feeding has been shown to greatly improve not only egg and sperm quality but also gonads development and fecundity are affected by certain essential dietary nutrients, especially in continuous spawning with short vitellogenic periods. Thus, more attention has been paid to the level of different nutrients in brood stock diets. However, studies on brood stock nutrition are limited.

From the results of GC analysis; MSEE contains antioxidants such as (quercetin $3^{\prime}$-methyl ether, quercetin 3,5,7,3',4'-pentamethyl ether , ascorbic acid, permethy, 17, 4'-Dimethoxy-3-hydroxyflavone, Citronellic acid and Squalane) ); highly unsaturated fatty acids (Linolenic acid, Tetradecanoic acid and Tetracosanoic acid); vegetable vitamins (Ascorbic acid and Vitamin E) is soluble in alcohol;. The results of GC analysis; MSPEE contains a high ratio of vitamin $\mathrm{E}$ due to miscible with petroleum ether.

The results showed significantly increased in the fry number/pond, the fry number /female and female average wt $(\mathrm{g})$ in all Moringa treatments 
when compared with the control group and this results agree with Latoya et al., (2013) who reported that animal studies have shown that the supplementation of Moringa on the diet as a source of vitamins and minerals can improve the quality of reproduction and overall growth performance; and concluded that nutritive content of Moringa is sufficient to maintain and enhance the quality of reproductive and overall health in zebrafish. These study results were similar with (Wahbi and Sangak, 2017) who concluded that the Spirulina in fish feeds improve reproduction performance of Tilapia fish. The major bioactive compounds of phenolics were flavonoid groups such as quercetin and these agree with our results of GC. On the basis of the results obtained, Moringa seeds are found to be a potential source of natural antioxidants due to their marked antioxidant activity (Perumal and Klaus 2003). The results of $(\mathrm{RBC})$ and $(\mathrm{Hb})$ were significantly increased in all treatments compared with control group. This elevation in erythrocytic count, haemoglobin content post using Moringa may be due to presence of saponin in Moringa (Khalil and Eladawy, 1994) or alkaloids and flavonoids in Moringa induce increase in total erythrocytic count, haemoglobin content and packed cell volume \% (Anwar and Rashid, 2007).

Moringa seed contains a large quantity of tecopherol (Mani et al, 2007). Lipid and fatty acid composition of brood stock diet have been identified as major dietary factors that determine successful reproduction and survival of spring. During spawning season, highly unsaturated fatty acids (HUFA) in brood stock diets increases fecundity, fertilization and egg quality. Ascorbic acid has also been shown to play an important role in salmonid reproduction, Vitamin E deficiency affects reproductive performance, causing immature gonads and lower hatching rate and survival of offspring. Elevation of dietary $\alpha$-tocopherol levels has been found to reduce the percentage of abnormal eggs and increase fecundity in the gilthead seabream (Sparus aurata) (Izquierdo et al., 2001).

O'donnel et al., (2001) stated that, testosterone produced by Leydig cells is responsible for spermatogenesis as well as for the development and maintenance of male secondary sex characteristics. This means that the amount of plasma testosterone is related to the capacity of the Leydig cells to secrete testosterone in the animal testis (Ewing et al., 1979). Our results showed significant increases in T2, T3 and T4 in testosterone hormone level in serum of male Nile Tilapia and significant increases of testis weight and GSI in T4 and T5. This results were agree with the finding of (Zade et al., 2013) who concluded that Moringa seeds aqueous 
extract enhanced sexual behavior of male albino rats. On the other hand, estradiol (E2) is the main sex hormone in female which play an important role in sexual development and responsible for estrogenic activity. It is produced mainly by the ovaries and in smaller amounts by the adrenal glands. Estradiol levels hypophysiotropic hormones and neuromodulators of reproductive behaviors (Ibrahem, 2013). The significant increases in ovary weight, gonad somatic index and estradiol hormones in T3, T4and T5 in serum of females Nile tilapia after fed with diet containing 0.5 and $1 \mathrm{mg}$ of MSEs/kg. may be due to MSEs contains antioxidants such as (quercetin, ascorbic acid, highly unsaturated fatty acids (Linolenic acid) and vitamin E. These results agree with the result of Mehrad and Sudagar (2010) who reported that vitamin E caused higher gonadosomatic index, larger ova, and more eggs than a control in a study on the effect of vitamin $\mathrm{E}$ and growth hormone on the gonadal maturity of fresh water fish (Cyprinus carpio). In addition, Mehrad and Sudagar (2010) concluded that complete spawning occurred in fish fed a diet containing vitamin E, but only partial spawning occurred in the fish fed diets without vitamin $\mathrm{E}$. The number of fries of fish was increased with increasing the level of dietary vitamin $\mathrm{E}$.

The HSI is a useful biomarker to detect hazardous effects of environmental stressors. There were significant decreases of HSI among the treatments compared with control group. These results indicate that MSEs had no hazardous effect on the fish. These finding was in agreement of that Gbadamosi et al., (2016) who concluded that moringa leaf protected the membrane integrity of the liver cells against stressors. These results seed also similar with Aja et al., (2014) who concluded that administration of aqueous, ethanolic and methanolic seed extracts of Moringa oleifera significantly reduced the levels of some liver enzymes in albino rats. They also observed that the liver pathology showed that no significant lesions were observed and this may point to the fact that the seed of Moringa oleifera is relatively safe for use medicinally.

\section{Conclusion}

M. oleifera seeds petroleum ether extract gives high yield of vitamin E than ethanol extract than petroleum ether extract. Supplementation of $M$. oleifera seeds extracts in feeds for O.niloticus brood stock increase number of fry, sexual hormones and GSI for males and females of brood stock; we conclude that $M$. oleifera seeds petroleum ether extract in lower dosage $(0.5 \mathrm{~g} / \mathrm{kg})$ has the potential to be used as a supplement in fish diets. The use of Moringa seeds extractions as feed additive in fish increase reproduction performance and enhance physiological state. 


\section{REFERENCES}

Abdel-Naby, A.S. 2014. Improvement productive performance using natural and biological products as feed additives in practical diets for Nile tilapia, oreochromis niloticus. Ph.D. degree of Science, Chemistry department, Faculty of Science, Zagazig University.

Abraham, G. E., 1977. Handbook of Radio-Immunoassay, 96 p.

Aja P.M., Nwachukwu N., Ibiam A.U., Igwenyi I.O.and Onu P.N., 2014. Comparative Evaluation of Transaminases and Alkaline Phosphatase Activities in Albino Rats Administered Aqueous, Ethanolic and Methanolic Extracts of Moringa oleifera Seeds Locally Grown in Abakaliki, Nigeria, Journal of Biological and Chemical Research, Volume 31 (1):164-181.

Ampofo-Yeboah, A., Brink D. and Lambrechts H., 2013. The Effect of Moringa Seed Powder Moringa Oleifera on Gonadal Integrity of Mozambique Tilapia Oreochromis mossambicus. World Aquaculture Society: Aquaculture. Thesis (PhD)--Stellenbosch University, 2013

Anwar Farooq, Sajid Latif, Muhammad Ashraf and Anwarul Hassan Gilani, 2007. Moringa oleifera: A Food Plant with Multiple Medicinal Uses. Phytother. Res. 21, 17-25.

Anwar, F. and Rashid U., 2007. Physicochemical characteristics of Moringaoleifera seeds and seed oil from a wild provenance of Pakistan. In Pakistan Journal of Botany, vol. 39, p. 1443-1453.

Bamidele N.A, Obasa S.O, Ikeiwenwe N.B, Abdulraheem I, Adeoye A.A, Odebiyi O.C., 2015. Effect of dried moringa (Moringa Oleifera) seed meal based diets on the growth, hematological, biochemical parameters and histopathology of the African Catfish, Clarias gariepinus fingerlings International Journal of Fisheries and Aquatic Studies 2015; 2(4S): 27-34

Dacie, S. V. and Lewis S. M., 1991. "Practical Hematology". $7^{\text {th }}$ Ed., Churchill Livingstone, London. pp: 556.

Ewing, L. L.; Zirkin, B. R.; Cochran, R. C.; Kromann, N.; Peters, C. and Ruiz-Bravo, N., 1979. Testosterone secretion by rat, rabbit, guinea pig, dog and hamster testes perfuse in vitro: correlation with leydig cell mass. Endocrinology, 105 (5): 1135-1142.

FAO (Food and Agriculture Organization) 2016. Aquaculture Big Numbers. Fisheries and Aqua. Technical. 601:2070-7010. Rome, Italy.

Ferreira RS, Napoleão TH, Santos AF, S'a RA, Carneiro-da- Cunha MG, Morais MM, 2011. Coagulant and antibacterial activities of the 
water-soluble seed lectin from Moringa oleifera. Lett Appl Microbiol 2011; 53(2): 186-192.

Gbadamosi Oluyemi K., Adedayo E. Fasakin, Olabode T. Adebayo (2016) Hepatoprotective and stress - reducing effects of dietary Moringa oleifera extract against Aeromonas hydrophila infections and transportation-induced stress in Nile tilapia, Oreochromis niloticus (Linnaeus 1757) fingerlings International Journal of Environmental \& Agriculture Research (IJOEAR) ISSN:[2454-1850] [Vol-2, Issue-7. Giorgini, G.; Conti, C.; Ferraris, P.; Sabbatini, S.; Tosi, G., 2010. Effects of Lactobacillus rhamnosus on zebrafish oocytes maturation: an FT-IR imaging and biochemical analysis. Anal Bioanal Chem 398: 3063 3072.

Ibrahem, M. D., 2013. Evolution of probiotics in aquatic world: Potential effects, the current status in Egypt and recent prospectives. Journal of Advanced Research.

Izquierdo, M.; Palacios, H. and Tacon, A., 2001. Effect of broodstock nutrition on reproductive performance of fish. Aquaculture.197, (1-4): 25-42.

Jabeen R, Shahid M, Jamil A, Ashraf M., 2008. Microscopic evaluation of the antimicrobial activity of seed extracts of Moringa oleifera. Pak J Bot 2008; 40: 1349-1358.

Jahn, S.A.A., Jahn Samia-Al Azh-Aria and Al-Azharia, J.S., 1986. Water treatment with traditional plant coagulant and clarifying clay. Record 10 and 26 CAB Abstract 1987-1989.

Khalil, A. and T. Eladawy, 1994. Isolation, identification and tox-icity of saponins from different legumes. Food Chemistry, 50(2): 197-201.

Latoya T. Paul, Lauren A. Fowler, Robert J. Barry, and Stephen A. Watts, 2013.Evaluation of Moringa oleifera as a dietary supplement on growth and reproductive performance in zebrafish. J Nutr Ecol Food Res. 2013 Dec; 1(4): 322-328.

Mani S.,Jaya S., and Vadivambal R., 2007. Optimization of Solvent Extraction of Moringa (Moringa Oleifera) Seed Kernel Oil Using Response Surface Methodology. Food and Bioproducts Processing Volume 85, Issue 4, December 2007, Pages 328-335.

Mehrad B, and Sudagar M., 2010. Dietary vitamin E requirement, fish performance and reproduction of guppy (Poecilia reticulata) AACL Bioflux, 2010, Volume 3, Issue 3, 239-246. 
Munkittrich K. R. and Dixon D. O., 1988. Growth, fecundity and energy store of white suckers (Catastomscommersons) from lakes containing elevated level of copper and zinc. Can. J. Fish. Aquatic.Sci., 45:1355- 1365.

NRC, 1993. [National Research Council].Nutrient requirements of fish. National Academy Press, Washington, DC, pp: 114, USA.

Obioma UN and Adikwu MU., 1997. Investigation on some physiochemical antioxidant and toxicological properties of Moringa oleifera seed oil. Acta Pharm 47: 287-290.

Ogbunugafor, H.A, - Eneh, F.U, - Ozumba, A.N, - Igwo-Ezikpe, M.N, -Okpuzor, J, - Igwilo, I.O, - Adenekan, S.O. and Onyekwelu, O.A., 2011. Physico-chemical and anti-oxidant properties of Moringa oleifera seed oil. In Pakistan Journal of Nutrition, vol. 10, no. 5, p. 409-414.

Ogunjinmi Oluwasayo Esther and Oladipo-Abodunwa Taiwo, 2012.

Preliminary test of phytochemical screening of crude extracts of moringa oleifera seed. Journal of Applied Chemistry (IOSR-JAC)ISSN: 22785736. Volume 3, Issue 2 (Nov. - Dec. 2012), PP 11-13.

O’donnel, L.; Robertson, K. M. and Jones, M. E., 2001. Estrogen and spermatogenesis. Endocrinol, 22: 280-318.

Olorode, O.O., Idowu, M.A., Bamgbose, A. and Ayano, A.E., 2014. Chemical phytochemical and functional properties of selected seeds flour.International. Journal of Nutrition and Food Sciences, Vol. 3, No. 6, 2014, pp.572-578.

Olugbemi, T.S, Mutayoba, S.K. and Lekule, F.P., 2010. Effect of Moringa (Moringa oleifera) Inclusion in Cassava based diets to broiler chickens. In International Journal of Poultry Science, vol. 9, no. 4, p. 363-367.

Perumal Siddhuraju and Klaus Becker, 2003. Antioxidant properties of various solvent extracts of total phenolic constituents from three different agroclimatic origins of drumstick tree (Moringa oleifera Lam.) leaves. J. Agric. Food Chem., 2003, 51 (8), pp 2144-2155.

Price, M.L., 2000. The Moringa tree. ECHO Development Note.

Tamhane, A.C. and Dunlop D.D., 2000. Statistics and Data Analysis from Elementary to Intermediate. Upper Saddle River. USA.

Vankampen, E.J., 1961. Determination of hemoglobin.Clin.Chem. Acta., 6: 538- 544. 
Wahbi O.M. and Sangak Y., 2017. Enhancement of Reproductive Performance of Nile Tilapia Oreochromis niloticus using Phytobiotic Spirulina platensis. Journal of Biological Sciences, 17: 305-311.

Welker, T. and C. Lim, 2011. Use of probiotics in diets of Tilapia. J Aquac Res Dev S 1: 2.

Worku Alemayehu, 2016. Moringa oleifera as a potential feed for live stock and aquaculture industry. African journal of agricultural science and technology (AJAST) Vol. 4, Issue 4, pp. 666-676. April, 2016.

Xing, S.; S.Z. Cekan and Diczfalusy U.E., 1983. Validation of radioimmunoassay for estradiol $\beta 17$ by isotope dilution as spectrometry and by a test of radiochemical purity. Clin. Chem. Acta, 135, 189-201.

Zade S. V.; Dinesh K. D.; Vaibhao G. T. and Shital R. P., 2013. Effect of Aqueous Extract of Moringaoleifera Seed on Sexual Activity of Male Albino Rats. Biological Forum - An International Journal 5(1): 129-140. 


\section{التغيرات البيوكيميائية على تكاثر أسماك البلطى النيلى بعد تغذيتها بمستخلصات}

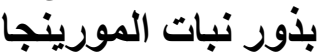

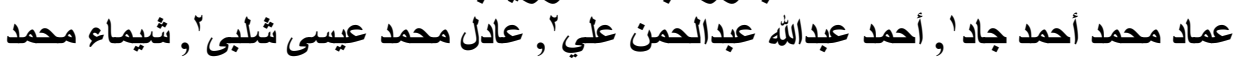

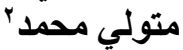

'قسم الكيمياء بكلية العلوم جامعة قناة السويس- فرع الإسماعلية.

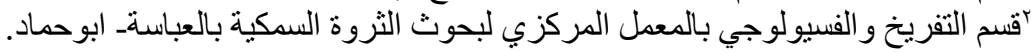

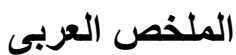

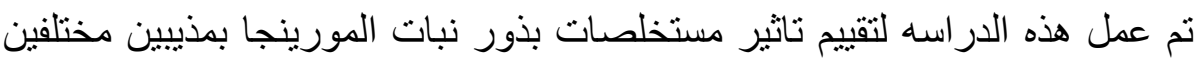

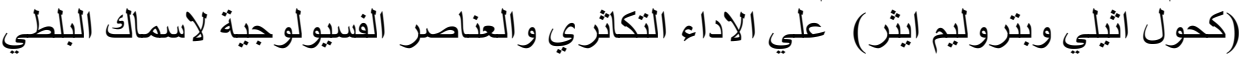

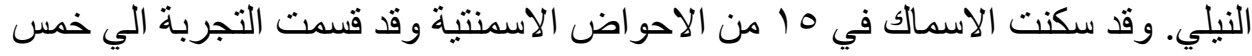

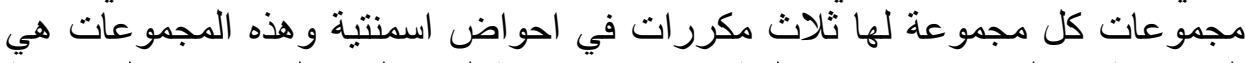

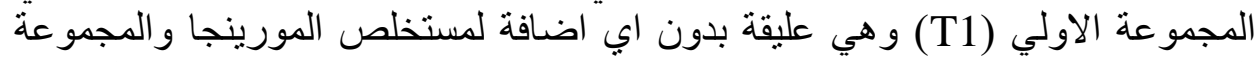

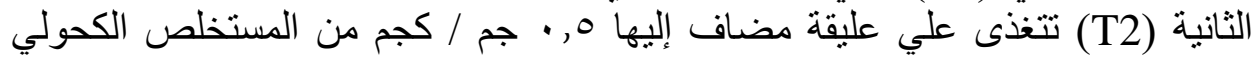

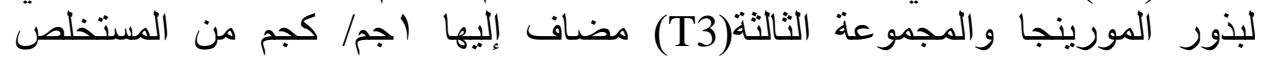

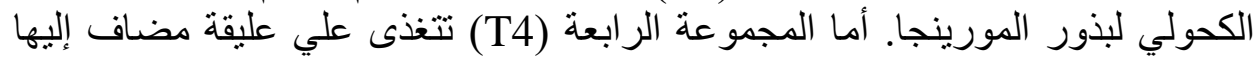

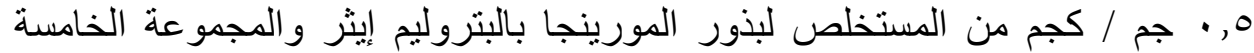

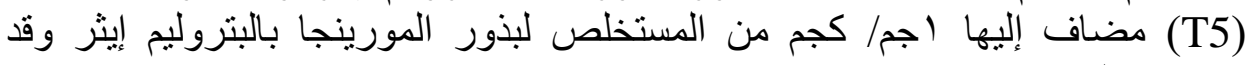
استمرت التجربه • V يوم.

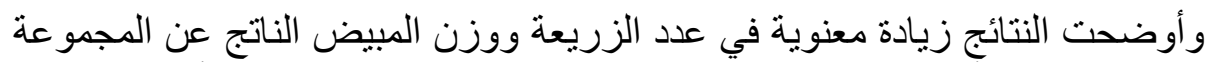

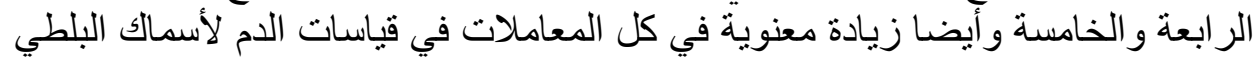

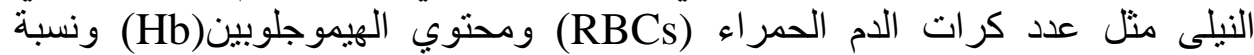

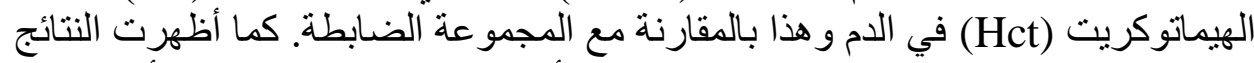

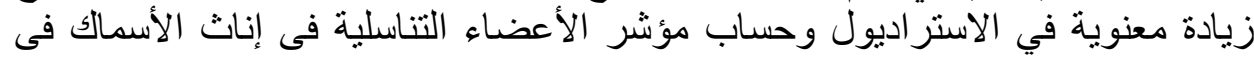

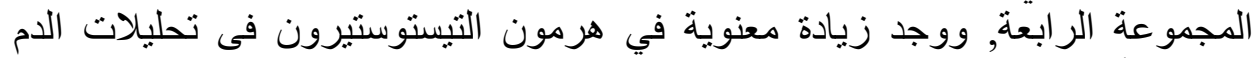

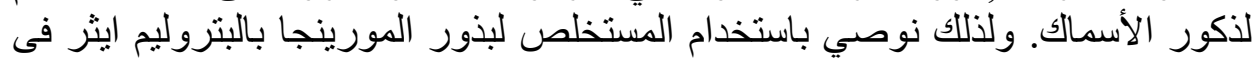

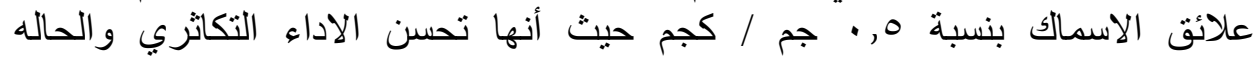

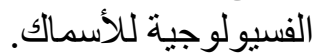

